Article - Biological and Applied Sciences

\title{
Use of Inert Gases for the Preservation of Nuclear Blood Cells
}

\author{
Andrey Nikolaevich Khudyakov ${ }^{1^{*}}$ \\ https://orcid.org/0000-0003-3757-8263
}

Tatyana Vitalyevna Polezhaeva ${ }^{1}$

https://orcid.org/0000-0003-4999-3077

Oksana Olegovna Zaitseva ${ }^{1}$

https://orcid.org/0000-0001-9427-0420

Marta Igorevna Sergushkina ${ }^{1}$

https://orcid.org/0000-0002-3113-527X

\section{Olga Nurzadinovna Solomina ${ }^{1}$}

https://orcid.org/0000-0002-3307-1951

Institute of Physiology of Komi Scientific Centre of the Russian Academy of Sciences FRC Komi SC UB RAS, Laboratory of Cryophysiology of Blood; Syktyvkar, Komi Republic, Russia.

Received: 2018.04.28; Accepted: 2019.03.30.

* Correspondence: defender36@yandex.ru; Tel.: +7-8212-240085 (work phone)

\section{HIGHLIGHTS}

- The use of gas cryoprotectants (CP) is an alternative to standard liquid CPs.

- A special portable low-pressure container was used for research.

- Xenon and krypton at the pressure of $0.6 \mathrm{mPa}$ do not affect the leukocyte parameters.

- The Inert gases have cryoprotectant effect, but requires further study.

Abstract: The subject of the study was the stability of human white blood cell membranes subject to noble gases (xenon ad krypton, $0.6 \mathrm{mPa}$ ) clathrate cryoanabiosis $\left(-80^{\circ} \mathrm{C}\right)$. A unique portable stainless steel low pressure container with a compartment for flexible plastic container was designed to ensure that the cells are saturated with gases. The samples were warmed after 1 and 30 days in a water bath $\left(+38^{\circ} \mathrm{C}\right)$ for $35-50 \mathrm{sec}$, while the container was being tilted (2-3 times per second), until the temperature of the biological object reached $+3 \pm 1^{\circ} \mathrm{C}$. It was demonstrated that after 30 days of clathrate anabiosis $\left(-80^{\circ} \mathrm{C}\right.$ ) over $95 \%$ (of the original number) of leukocytes remain viable, and cell membranes of $54.5 \pm 3.4 \%$ of them is resistant to trypan blue; granulocyte survival rate is $73.5 \pm 2.7 \%$, original lipid peroxidation rate and antioxidant activity are retained. Biological object cryopreservation in noble gases environment is a promising trend in biology and medicine.

Keywords: clathrates, cryopreservation, xenon, krypton, leukocytes. 


\section{INTRODUCTION}

Traditional biological object cryopreservation techniques are based on the use of liquid cryoprotectors (CP), i.e. chemicals of various classes that may be toxic and may require washing off the sample [1]. A promising development in the search for new, safe and effective cryophilactic agents can be the use of non-toxic noble gases. In 1961 L.Pauling, a US scientist noticed that microcrystals of noble gas hydrates emerging in the water medium contribute to the inhibition of bioelectric activity and cell metabolism [2]. These studies came under notice of numerous biologists and medical scientists. Russian scientists headed by Academician V.V. Kovanov in the 1980s proved that bio objects saturated with heavy noble gases such as argon, krypton and xenon at low temperatures and high pressure are capable of transitioning to the state of anabiosis without the use of traditional CPs. This phenomenon is linked to the fact that noble gases can form hydrate compounds with the cellular water molecules [3-7]. Gas hydrates are of the clathrate type being non-ice loose crystallic structures which integrate into the intracellular architecture without damaging the membranes. When ice nuclei as clathrate structures start to emerge in the biocells, these microparticles initiate crystallization of free water. Crystallization runs a complete course along the whole of the cooled object at the same time without damaging cell membranes.

Such noble gas as xenon is widely used in practical medicine $[8,9]$. It has no acute or chronic toxic properties [10-12], is not allergenic [13], is highly soluble in lipids [14], has anti-apoptotic effect on cells [15] and forms crystalline hydrates with water $[16,17]$ to reduce its molecular and protein mobility [18-20]. Krypton is very similar to xenon in their characteristics, but the biological effects of krypton is poorly studied [21,22].

Recently, taking into account the special properties of inert gases, works is underway to use them for cryopreservation of organs and tissues. S. Sheleg successfully performed mouse cardiomyocyte freezing in a low pressure chamber in xenon/oxygen environment in liquid nitrogen vapors. Electronic microscopy data confirm that the above gas mixture effectively preserves cell mitochondria [23]. Xenon was also used for freezing stem cells and fragments of human skin [24]. It should be noted that the above research on bio object freezing in gas environments is performed using liquid nitrogen. Possibility of preservation of cell suspensions in clathrate anabiosis at the temperatures maintained in electric freezers has not been studied.

The purpose of this study is to determine if the use of noble gases for preservation of human white blood cells at $-80^{\circ} \mathrm{C}$ is effective. The results will be a foundation for development of new techniques of long-term preservation of human cells, tissues and organs.

\section{MATERIAL AND METHODS}

A portable low-pressure container was designed and manufactured for saturating the cells with gas [25]. It has a selection of programs to perform cell suspension preservation by freezing under the pressure created by gases. The device comprises (Figure 1) two stainless steel panels, their total weight being $4520 \mathrm{~g}$, which are joined along the perimeter on steel bolts. 


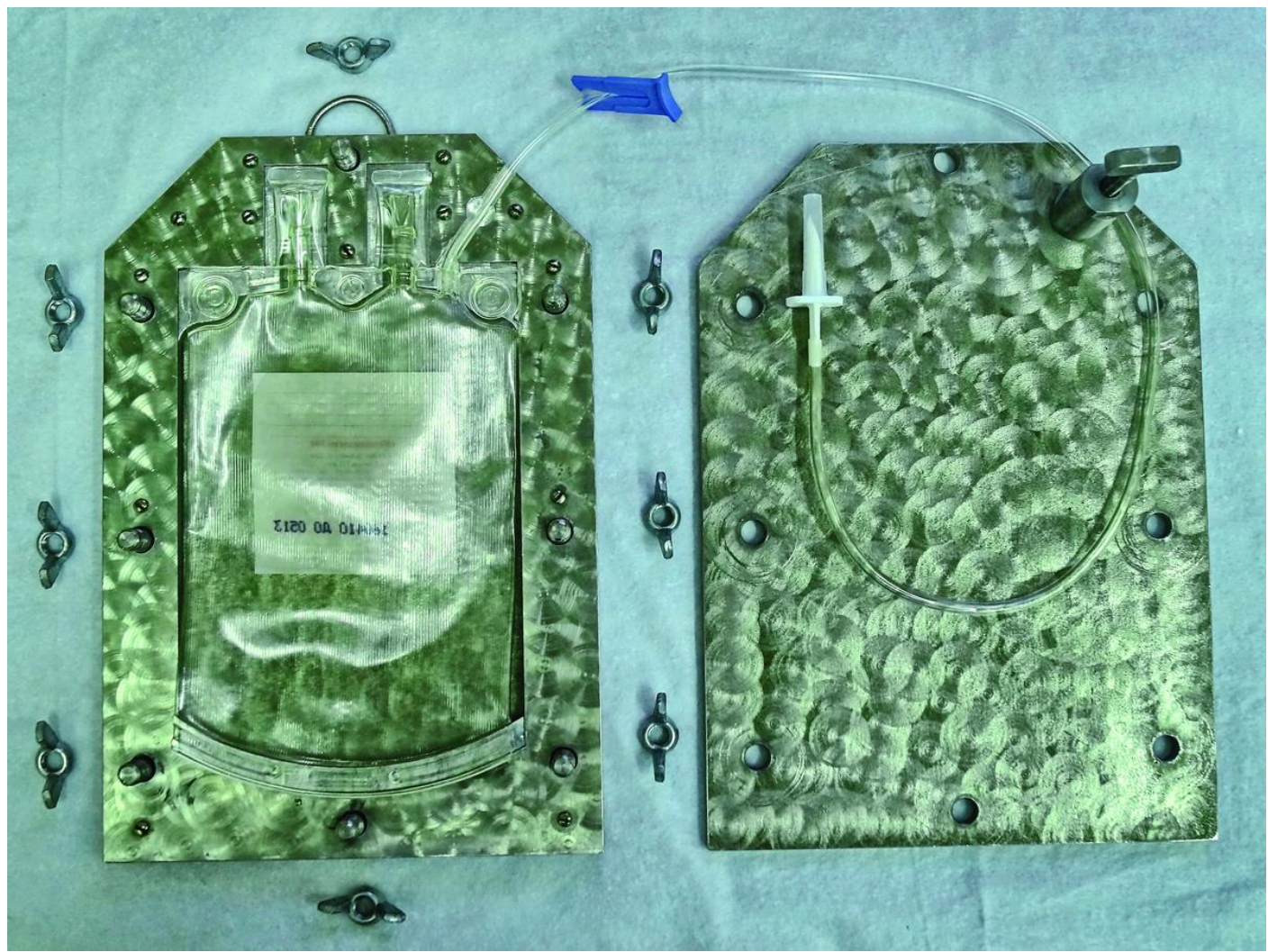

Figure 1. Portable, pressure-resistant container with a plasticate container inside for cell suspensions.

The container has a compartment that corresponds exactly to the volume and dimensions of the standard Compoplast 300 (OJSC "Syntez", Russia) flexible plasticate container, which can be cooled to $-80^{\circ} \mathrm{C}$. In the upper section there is a channel for the main pipe of the flexible plastic container, which is used to pump through the gas after the device is completely assembled. The pipe can be blocked by a clamp (a screw with a shunt).

The samples were leukocyte concentrates $(n=50)$, extracted from volunteer donor blood by cytapheresis using Sorvall centrifuge (Thermo Electron LED GmbH, Germany) with 3870 $g$-force. Average volume (after the cytapheresis process) of each tested bio object was $16 \pm 2$ $\mathrm{ml}$. Average age of the donors was $32 \pm 4$ years.

Leukocyte concentrates were placed inside the Compoplast 300 flexible plasticizer containers, then into the low pressure container, where they were saturated with xenon at $0.6 \mathrm{mPa}$, conditioned at normal ambient temperature $\left(21^{\circ} \mathrm{C}\right)$ for 20 minutes (Figure 2).

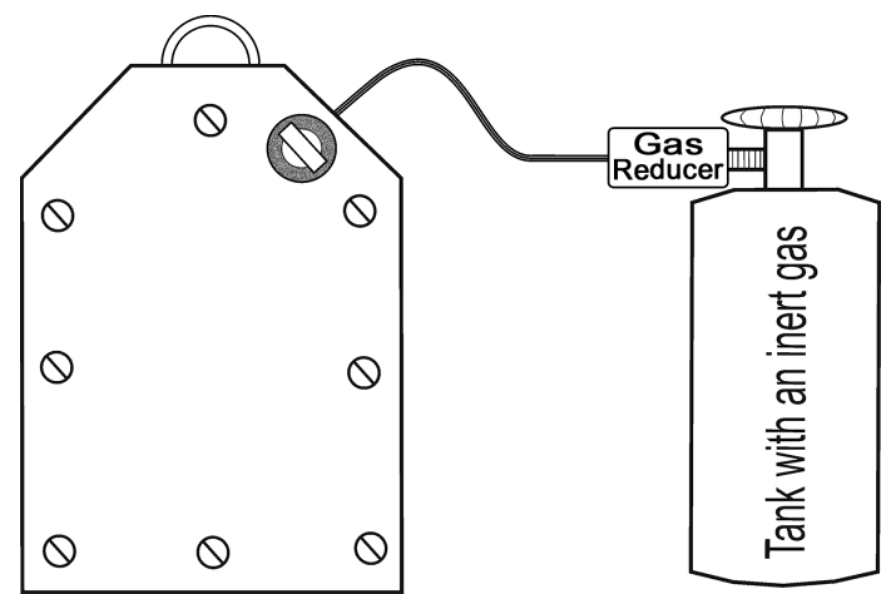

Figure 2. Installation for gas saturation of cells (concept). 
The flexible plastic container was removed from the metal container as soon as excess gas was extracted. The biological object was frozen in two phases: first in an alcohol $\left(96^{\circ}\right)$ bath cooled to $-28^{\circ} \mathrm{C}$ in the Kriostat electric freezer (Institute for Problems of Cryobiology and Cryomedicine, Ukraine) for 15 minutes, then transferrred to the air chamber of the electric freezer at $-80^{\circ} \mathrm{C}$, where it was kept for 1 and 30 days. The samples were warmed in a water bath $\left(38^{\circ} \mathrm{C}\right)$ for $35-50 \mathrm{sec}$, while the container was being tilted (2-3 times per second), until the temperature of the biological object reached $+3 \pm 1^{\circ} \mathrm{C}$.

The following values were assessed using light microscopy Nikon H550S (Nikon Corporation, Japan): total number of cells in Goryaev chamber; cryoresistance of different cell populations in smears immersed in May-Grünwald and Romanowsky stains; integrity of cell membrane in samples immersed in 1.0\% trypan blue supravital stain solution [26].

A lipid peroxidation (LPO) rate and antioxidant activity (AOA) in membranes was evaluated by induced chemiluminiscence using the BCL-07 biochemoluminometer (MEDOZONS Ltd., Russia) as follows: $0.1 \mathrm{ml}$ of leukocyte concentrate and $0.4 \mathrm{ml}$ of phosphate buffer $(\mathrm{pH}=7,5)$ were introduced into the measuring cell of the biochemiluminometer, and $0.4 \mathrm{ml}$ of the $0.01 \mathrm{mM}$ iron sulfate solution was added, further, $0.2 \mathrm{ml}$ of a $2 \%$ hydrogen peroxide solution was added to this mixture,, and the CL signal was being registered for 30 seconds. LPO rate was evaluated using the following indicators: S $(\mathrm{mV} \times \mathrm{sec}$, light sum over 30 seconds calculated as the area under the sample glow curve which correlates with $\mathrm{RO} 2$ radicals content equivalent to free-radical oxidation chains. Antioxidant potential was evaluated using the $\operatorname{tg}(-2 \alpha)$ value, i.e. slope of the curve of the time axis (describes maximum curve gradient, with the minus sign); the higher is $\operatorname{tg}(-2 \alpha)$, the higher is the activity of cell enzyme systems that regulate hydroperoxide content.

Statistical data manipulation involved calculation of arithmetic mean value \pm standard deviation $(\mathrm{M} \pm \delta)$. Wilcoxon signed-rank test was applied to determine statistical significance of differences $(p<0.05)$ between the groups using BIOSTAT, a computer application for medical and biological statistics [27].

\section{RESULTS AND DISCUSSION}

It was determined that xenon and krypton at the pressure of $0.6 \mathrm{mPa}$ do not affect the leukocyte parameters at normal ambient temperature. For example, total number of cells, their structure, membrane resistance to the vital stain, LPO rate and antioxidant activity are the same as the values before gas saturation. This confirms the data on the lack of significant influence of these inert gases on the biological indicators of cells in a short-term saturation (20 min) $[12,15,22,24]$. However, it should be clarified that when exposed to the whole organism, both xenon and krypton can change the blood indicators, such as the number of leukocytes and the content of some steroids and glucocorticoids [28].

It was found (see Table 1), that leukocyte viability parameters after 1 and 30 days in cryoanabiosis (with xenon) demonstrate no statistically significant difference. A granulocyte survival rate after warming remains relatively high (83-90\%). However, when using krypton an indicator of the number of leukocytes statistically decreased in comparison with indicators when using xenon. It could be connected with the fact that under these conditions krypton form clathrates less than xenon. 
Table 1. Indicators of leukocyte preservation $(n=10 ; M \pm \sigma)$ after xenon clathrate anabiosis $\left(-80^{\circ} \mathrm{C}\right)$ for various periods of time.

\begin{tabular}{|c|c|c|c|c|c|c|}
\hline \multirow{3}{*}{$\begin{array}{c}\text { Storage } \\
\text { period, } \\
\text { days }\end{array}$} & \multicolumn{6}{|c|}{ Preservation indicators } \\
\hline & \multicolumn{2}{|c|}{ Number of leukocytes } & \multicolumn{2}{|c|}{ Trypan blue resistance } & \multicolumn{2}{|c|}{$\begin{array}{l}\text { Number of } \\
\text { granulocytes }\end{array}$} \\
\hline & $\mathrm{Xe}$ & $\mathbf{K r}$ & $\mathbf{X e}$ & $\mathbf{K r}$ & $\mathbf{X e}$ & $\mathbf{K r}$ \\
\hline 1 & $98.6 \pm 2.5$ & $81.0 \pm 6,1^{*}$ & $71.6 \pm 3.3$ & $68.2 \pm 11.7$ & $90.0 \pm 6.0$ & $86.1 \pm 4.6$ \\
\hline 30 & $97.6 \pm 1.2$ & $69.8 \pm 12.9$ * & $64.5 \pm 14.4$ & $64.2 \pm 9.6$ & $86.0 \pm 11.0$ & $83.1 \pm 4.9$ \\
\hline
\end{tabular}

Notes: Data are presented as a percentage relative to the level before freezing, taken as $100 \%$; * - statistically significant difference from the indicator value when using xenon ( $p$ $<0.05)$.

When cell suspension is exposed at normal ambient temperature, xenon and krypton easily permeate the plasma membrane and do not affect leukocyte LPO and AOA processes. However, due to their high solubility in cell membrane lipids, noble gases modify their permeability to ions, and when clathrates with free intracellular water are formed, it reduces molecular mobility to further inhibit metabolic rates and get the human white blood cells prepare to the cold. Cell membrane LPO rate and antioxidant activity analysis using the chemiluminogram shows (Figure 3 ) that these processes start being inhibiting after 30 days in preservation especially when used of krypton (indicator $\operatorname{tg}(-2 \alpha)$ ).

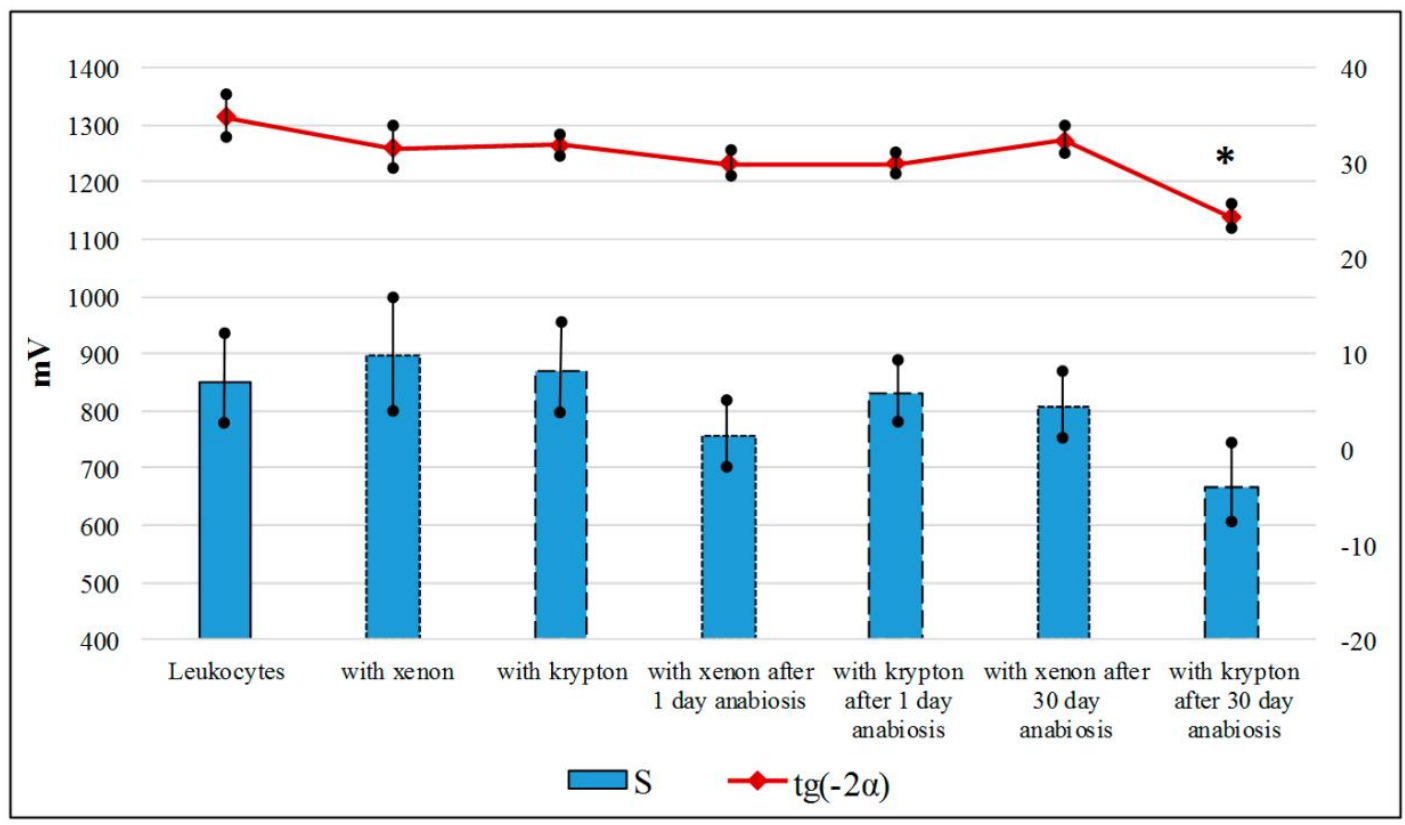

Figure 3. Installation for gas saturation of cells (concept).

Note: * - difference from the indicator value of leukocytes with xenon is statistically significant ( $p$ $<0.05)$.

We consider that longer preservation times are impractical, as the chemiluminogram shows a decline cell activity in system LPO and AOA. This is further confirmed by the result of vital stain tests. Most likely, clathrates lose their stability over time, and when the bio object is initially warmed, big ice crystals start to grow inside it and damage the intracellular architecture.

Leukocyte membrane survival rates after clathrate anabiosis for 24 hours, and 30 days confirm that these gases have a positive cryoprotectant effect. However, in order to prolong cell preservation time, an additional penetrant cryoprotector (glycerol, dimethyl sulfoxide, etc. in low concentrations) should be added to the biological medium. 
It should be noted, that the pressure of $0.6 \mathrm{mPa}$ used for cell suspension saturation does not require biomaterial decompression after warming. It was discovered at the initial stages of the research that xenon pressure of $0.9 \mathrm{mPa}$ causes intense foaming during warming which leads to cell death. It has been known that xenon clathrates lose their stability when the temperature during warming is increased, and change to the gas phase $[29,30]$. For this purpose, if there is enough water to dissolve noble gases, they can be gradually removed from the cells. The use of inert gases for cryopreservation avoids many of the conventional negative effects of ice on the cells. Also, gases, unlike liquid CPs, are able to quickly penetrate the entire volume of the object, this is very important for cryopreservation of organs and large tissue fragments.

\section{CONCLUSION}

As shown in this study inert gases have cryoprotectant effect, despite the danger of cell destruction during clathrate thawing, and the use of gas cryoprotectors is a promising development and requires further study.

Funding: This research received no external funding.

Conflicts of Interest: The authors declare no conflict of interest.

\section{REFERENCES}

1. Svedentsov, E.P. Cryoprotectant for living cell. Syktyvkar: Physiology Institute at the Komi Scientific Center of the Russian Academy of Sciences; 2010.

2. Pauling, L. A molecular theory of general anesthesia. Science 1961, 134, 15-21. DOI: 10.1126/science.134.3471.15

3. Englezos, P. Clathrate hydrates. Ind Eng Chem Res 1993, 32, 1251-1274. DOI: 10.1021/ie00019a001

4. Preckel, B.; Weber, N.; Schlack, W. Xenon - noble gas with organprotective properties. Anasthesiol Intensivmed Notfallmed Schmerzther 2004, 39, 456-462. DOI: 10.1055/s-2004-825736

5. Sloan, E.D.; Koh C.A. Clathrate hydrates of natural gases. Boca Raton: CRC Press, Taylor \& Francis Group; 2008.

6. Telpoukhov, V.I.; Schcherbakov, P.V. Clathrate cryopreservation. Issues of Reconstructive and Plastic Surgery 2012, 3(42), 77-80.

7. Shishova, N.V.; Fesenko, E.E. The prospects of the application of gases and gas hydrates in cryopreservation. Biophysics 2015, 60, 782-804. DOI: 10.1134/s0006350915050218

8. Khlusov, I.A.; Naumov, S.A.; Wovk, S.M.; Kornetov, N.A.; Shpisman, M.N.; Lukinov, A.V.; Naumov, A.V. Effect of xenon on cells and receptors. Vestn. Ross. Akad. Med. Nauk 2003, 9, 32-37.

9. Fahlenkamp, A.V.; Coburn, M.; Rossaint, R.; Stoppe, C.; Haase, H. Comparison of the effects of xenon and sevoflurane anaesthesia on leucocyte function in surgical patients: a randomized trial. Br J Anaesth 2014, 112, 272-280. DOI: 10.1093/bja/aet330

10. Burov, N.E.; Makeev, G.N.; Potapov, V.N. Applying xenon technologies in Russia. Appl. Cardiopulm. Pathophysiol 2000, 9(2), 132-133.

11. Ma, D.; Hossain, M.; Pettet, G.K.; Luo, Y.; Lim, T.; Akimov, S.; Sanders, R.D.; Franks, N.P.; Maze, M. Xenon preconditioning reduces brain damage from neonatal asphyxia in rats. J Cereb Blood Flow Metab 2006, 26, 199-208. DOI: 10.1038/sj.jcbfm.9600184

12. Lim, J.G.; Heo, Y.T.; Lee, S.E.; Jang, W.I.; Min, S.G.; Uhm, S.J.; Kim, N.H. A new modified cut standard straw vitrification technique reduces the apoptosis of mouse blastocysts and generates more live mouse offspring. CryoLetters 2013, 34(6), 598-607.

13. Joyce, J.A. Xenon: anesthesia for the 21st century. AANA Journal 2000, 68(3), 259-264.

14. Marx, T.; Kotzerke, J.; Musati, S.; Ring, C.; Schmidt, M.; Reinelt, H.; Frobba, G. Time constants of xenon elimination after anaesthesia. Appl Cardiopulm Pathophysiol 2000, 9(2), 91-96. 
15. Spaggiari S.; Kepp, O.; Rello-Varona, S.; Chaba, K.; Adjemian, S.; Pype, J.; Galluzzi, L.; Lemaire, M.; Kroemer, G. Antiapoptotic activity of argon and xenon. Cell Cycle 2013, 12, 2636-2642. DOI: $10.4161 / \mathrm{cc} .25650$

16. Ohgaki, K.; Sugahara, T.; Suzuki, M.; Jindai, H. Phase behavior of xenon hydrate system. Fluid Phase Equilibria 2000, 175, 1-6. DOI: 10.1016/S0378-3812(00)00374-5

17. Artyukhov, V.I.; Pulver, A.Yu.; Peregudov, A.; Artyuhov, I. Can xenon in water inhibit ice growth? Molecular dynamics of phase transitions in water-Xe system. J Chem Phys 2014, 141 (3). DOI: 10.1063/1.4887069

18. Damir, E.A.; Burov, N.E.; Makeev, G.N.; Djabarov, D.A. Narcotic properties of xenon and the prospects for its use in anesthesiology. Anesteziol. Reanimatol 1996, 1, 71-75.

19. Yamamoto, E.; Akimoto, T.; Shimizu, H.; Hirano, Y.; Yasui, M.; Yasuoka, K. Diffusive nature of xenon anesthetic changes properties of a lipid bilayer: molecular dynamics simulations. $J$ Phys Chem B 2012, 116, 8989-8995. DOI: 10.1021/jp303330c

20. Booker, R.; Sum, A.K. Biophysical changes induced by xenon on phospholipid bilayers. Biochim Biophys Acta Biomembr 2013, 1828, 1347-1356. DOI: 10.1016/j.bbamem.2013.01.016

21. Moschetti, T.; Mueller, U.; Schulze, J.; Brunori, M.; Vallone, B. The structure of neuroglobin at high $\mathrm{Xe}$ and $\mathrm{Kr}$ pressure reveals partial conservation of globin internal cavities. Biophys $\mathrm{J} 2009$, 97(6), 1700-1708. DOI: 10.1016/j.bpj.2009.05.059

22. Stupic, K.F.; Elkins, N.D.; Pavlovskaya, G.E.; Repine, J.E.; Meersmann, T. Effects of pulmonary inhalation on hyperpolarized krypton-83 magnetic resonance T1 relaxation. Phys Med Biol2011, 56(13), 3731-3748. DOI: 10.1088/0031-9155/56/13/001

23. Sheleg, S.; Hixon, H.; Cohen, B.; Lowry, D.; Nedzved, M. Cardiac mitochondrial membrane stability after deep hypothermia using a xenon clathrate cryostasis protocol - an electron microscopy study. Int J Clin Exp Pathol 2008, 1, 440-447.

24. Ponomarev, A.I.; Makeev, O.G.; Zvereva, A.I.; Korotkov, A.V. Applicability of the xenon clathrates protocol for skin grafts preservation. Vestn. Ural. Med. Akad. Nauki 2014, 5, 98-102.

25. Svedentsov, E.P.; Laptev, D.S. Device for freezing preserving of cell suspensions under pressure in inert gas atmosphere - portable cryobarocontainer. Russian patent, 2506748, A01N, F25D/2012.

26. Svedentsov, E.P.; Tumanov,a T.V.; Khudyakov, A.N.; Zaitseva, O.O.; Solomina, O.N.; Utemov, S.V.; Sherstnev, F.S. Cryopreservation of functionally active blood nuclear cell membranes at $-80^{\circ} \mathrm{C}$. Biochem. Moscow Suppl. Ser. A: Membrane and Cell Biology 2008, 1, 19-25. DOI: 10.1007/s11827-008-1004-9

27. Glanz S. Medicobiologic statistics. Moscow: Practice; 1998.

28. Kussmaul, A.R.; Bogacheva, M.A.; Shkurat, T.P.; Pavlov, B.N. Effects of xenon and krypton-containing breathing mixtures on clinical and biochemical blood indices in animals. Aviakosm. Ekol. Med 2007, 41(2), 60-63.

29. Derwall, M.; Coburn, M.; Rex, S.; Hein, M.; Rossaint, R.; Fries, M. Xenon: recent developments and future perspectives. Minerva Anestesiol 2009, 75, 37-45.

30. Mendes, F.; Gomes, M. Xenon: pharmacology and clinical use. Rev Brasil Anestesiol 2003, 53, 535-542. DOI: 10.1590/S0034-70942003000400013 